\title{
Corporate Financial Policies and the Exchange Rate Regime: Evidence from Brazil
}

\author{
José Luiz Rossi Júnior* \\ IBMEC São Paulo, Brazil
}

\begin{abstract}
Resumo
Este trabalho analisa o relacionamento entre a política financeira das empresas e o regime cambial para uma amostra de empresas brasileiras não-financeiras no período de 1996 a 2006. Os resultados indicam que, além de reduzir a proporção da dívida expressa em moeda estrangeira e aumentar a utilização de derivativos, a adoção de um regime de câmbio flutuante leva a um maior casamento monetário entre a ativo e o passivo das firmas. O trabalho mostra que esta melhora no gerenciamento de risco das firmas dá-se, principalmente, nas firmas mais expostas ao risco cambial. Os resultados confirmam que o regime cambial exerce um papel importante na determinação da vulnerabilidade externa das firmas.
\end{abstract}

Palavras-Chave: Dívida, Regime cambial, Exposição, Proteção, Derivativos.

\begin{abstract}
This paper analyzes the relationship between companies' financial policies and the exchange rate regime for a sample of non-financial Brazilian companies from 1996 to 2006. The results indicate that besides reducing the proportion of companies debt denominated in foreign currency and increasing the use of currency derivatives, the adoption of a floating exchange rate regime is shown to improve the match between the currency composition of companies' assets and liabilities. The paper also shows that this reduction in companies' currency mismatches is more pronounced for companies in the highest quantile of foreign exposure; therefore the results confirm that the exchange rate regime plays an important role in the determination of companies' foreign vulnerability.
\end{abstract}

JEL classification: F31; F41; G15; G32.

Keywords: Debt composition, Hedging, Use of derivatives, Exposure, Exchange rate regime.

Área: Macroeconomia, Economia Monetária e Finanças.

\footnotetext{
* Address: Rua Quatá 300, Vila Olímpia, São Paulo-SP, Brazil. Tel.: + 55114504 2437; Fax: +55 1145042350.

E-mail address: joselrj1@isp.edu.br
} 


\section{Introduction}

Adverse external shocks represent a key source of risk for emerging markets. In these countries, several episodes of crises and economic downturns were triggered by external factors. ${ }^{1}$ One question levied by the literature is whether the exchange rate regime plays a role in reducing countries' vulnerability to these shocks.

Following a sequence of financial crises in the 1990s, a new generation of currency crises models placed corporate behavior at the center of the debate about the relationship between countries' external vulnerability and the exchange rate regime. In these models, a fixed exchange rate regime would increase countries' vulnerability by leading companies to disregard the exchange rate risk, biasing their borrowing towards foreign currency denominated debt and/or reducing their hedging activities. ${ }^{2}$ In opposition, a floating exchange rate regime would help countries to mitigate their external vulnerability by inducing companies to take seriously their exchange rate exposure. ${ }^{3}$

To what extent the exchange rate regime can alleviate companies' foreign vulnerability by inducing changes in corporate financial policies is still an open question. Empirical studies in this area are still scarce. Martinez and Werner (2001) found that after the financial crisis in Mexico in 1995, companies reduced the currency mismatches in their balance sheets. Performing a similar test than Martinez and Werner (2001) for Brazilian companies between 1996 and 2004, Rossi (2007) confirms that implicit guarantees linked to the adoption of a fixed exchange rate regime biased corporate borrowing towards foreign currency denominated debt and that the floating regime alleviate this problem, leading companies to take seriously their foreign exposure. Similar results were found by Cowan, Hansen and Herrera (2005) for a sample of Chilean companies. The authors found that there was a reduction in the level of currency exposure after 1999 when the home currency was let to float. The authors argue that this reduction in exposure took place due to the fact that the floating regime eliminated implicit exchange rate insurance given to firms, forcing them to internalize the exchange rate risk. Departing from country-case studies, Kamil (2006) confirms using a sample of companies in seven different Latin-American countries that the adoption of a floating exchange rate regime leads to a higher degree of currency matching on companies' balance sheets.

This paper contributes to this literature by taking a systematic look at the relationship between companies' financial policies and the exchange rate regime. The analysis employs a unique database constructed directly from companies' annual reports containing information about the currency composition of the debt and the use of currency derivatives for a sample of non-financial Brazilian companies from 1996 to 2006, period in which Brazil adopted two different exchange rate regimes: a (quasi-) fixed and a flexible exchange rate regimes. This transition between two different exchange rate regimes provides an opportunity to analyze whether the adoption of different exchange rate regimes affects corporate foreign vulnerability by inducing changes in financial policies.

Consistent with the hypothesis that there is a relationship between corporate financial policies and the exchange rate regime, we find that the floating exchange rate regime led companies to improve their prudential measures to reduce their exchange rate risk. We show that the adoption of a floating exchange rate regime exerts a negative impact on companies' foreign currency borrowing and a positive effect on the use of currency derivatives, indicating that there is a reduction in the level of companies' unhedged foreign liabilities after the adoption of the floating regime.

In addition, the paper indicates that this is not the only impact of the adoption of a floating exchange rate regime. The paper shows that a reduction in the currency mismatches in companies' balance sheets takes place after the adoption of the floating exchange rate regime. Under a floating regime firms with higher proportion of foreign sales to total sales are more prone to keep unhedged liabilities and

\footnotetext{
${ }^{1}$ Examples are an abrupt rise in global interest rates, a fall in commodity prices or a weakening of global growth.

${ }^{2}$ Since these models argue that this behavior would arise due to the guarantees given by the government to companies, this branch of the literature is denominated the implicit guarantees hypothesis. Examples of this literature include Dooley (1997), Burnside et al. (1999) among others.

${ }^{3}$ Even among politicians, there is a strong concern that the high levels of foreign currency denominated debt led the country to be vulnerable to external shocks. "It is very important to everybody to realize that Brazil is still a vulnerable economy. We are vulnerable because we owe a lot, and a fraction of this debt is expressed in dollars.” Luis Inácio Lula da Silva, Brazilian President, 03/30/2004, O Globo.
} 
firms in the non-tradable sector are more likely to use currency derivatives. The paper also shows that this adjust in corporate financial policies that happen with the adoption on the floating regime are more pronounced for firms in the highest quantile of risk.

Following the discussion on corporate finance about the determinants of companies' capital structure, the paper also shows that besides the exchange rate regime, companies' access to financial markets, investment opportunities and liquidity are important determinants of their foreign currency borrowing and that fixed costs, the possibility of incurring in financial distress and investment opportunities play a role on the determination of their use of currency derivatives.

The paper proceeds as follows. In section 2, I describe the Brazilian experience under both exchange rate regimes and show the data that will be used throughout the text. Section 3 analyzes empirically the impact of the exchange rate regime on corporate financial policies and I estimate the main cross-sectional determinants of company's foreign borrowing and the use of currency derivatives. Section 4 summarizes the results and gives some policy implications.

\section{Macroeconomic Background and Data \\ 2.1 Macroeconomic Background}

After the stabilization plan in 1994 until January 1999, Brazil adopted a "crawling-band" exchange rate regime. ${ }^{4}$ During this period, Brazil suffered from several speculative attacks, especially during the Asian and Russian crises. The Central Bank reacted promptly to such attacks by raising interest rates in order to maintain the regime, demonstrating clearly its commitment to the exchange rate regime even at the cost of maintaining high interest rates, increasing the public debt, and causing an economic recession.

After a speculative attack in January 1999, currency was allowed to float, and an inflationtargeting regime was adopted. After tightening monetary and fiscal policies, Brazil succeeded in stabilizing inflation and the economy quickly recovered from the crisis. In 2002, due to the possibility that a new president against current policies would be elected, a reversal of capital flows took place and the exchange rate depreciated more than $50 \%$ during the year with a consequent rise in inflation. After 2003, home currency started to appreciate because the new government opted to reinforce the orthodox macroeconomic policy and a positive external shock represented by an increase in the price of the main exported commodities struck the country.

One fact that makes the Brazilian experience unlike the experience of other Latin-American countries is that "fear of floating" was not a significant characteristic of Brazilian monetary policy. Using the measure of "fear of floating" created by Calvo and Reinhart (2002), Kamil (2006) shows that among all countries used in his study, Brazil presented the highest value of its measure during the floating period indicating a high degree of flexibility, even higher than Chile and Mexico. Moreover, differently than other countries, the IMF De facto regime classification defines the period after 1999 as an independently floating regime. Therefore, in the Brazilian case, we have a patent division between the two exchange rate regimes adopted by the country.

\subsection{Data}

Data for this analysis was collected from both companies' annual reports and Economática, a database that contains stock market and financial data for all Latin-American publicly traded companies. I used a sample of Brazilian non-financial publicly traded companies from 1996 to 2006. The description of all variables used throughout the text is shown in the Appendix. The period from 1996 to 2006 was chosen not only because it is possible to compare the behavior of the companies under different exchange rate regimes, but also because the use of derivatives was required to be reported only after $1995 .^{5}$ The sample contains information for all companies that were in the database in 1996 and stayed until 2006, a total of 180 companies. This procedure was followed in order to give a better comparison of companies' behavior under the two different exchange rate regimes. ${ }^{6}$ All information was obtained from the

\footnotetext{
${ }^{4}$ Strictly speaking a system of bands was adopted with the top and bottom of the band being devalued at a fixed rate.

${ }^{5}$ Securities and Exchange Commission of Brazil - CVM instruction Nr. 235/1995.

${ }^{6}$ We also perform the estimations using all publicly traded companies. The results are unchanged.
} 
consolidated balance sheet in case a company has subsidiaries that are also publicly traded. The final sample comprises more than 50\% of all publicly traded companies in Brazil and $67.9 \%$ of all market capitalization.

Data about foreign sales, the currency composition of the debt and the use of currency derivatives was collected directly from companies' annual reports. Unfortunately, Brazilian companies do not have a systematic procedure to register information about their foreign sales. Sometimes it is reported together with a company's total gross sales, sometimes it is reported under the comments from the managers to shareholders, and sometimes it is found in the explanatory notes. In some cases, companies mention being exporters, but do not report the amount of foreign sales; in this case, I contacted the companies directly through electronic mail. I eventually discarded seven companies from my sample who mentioned being exporters but who neither reported the amount of their foreign sales nor answered my mail inquiries.

Information with respect to corporate foreign currency borrowing and the use of currency derivatives are available in the annual reports under the explanatory notes. The amount of foreign currency denominated debt is located under the item loans and financing and the use of derivatives is registered under the item financial instruments.

I use the total gross notional value of currency derivatives as my proxy for the extension of the use of currency derivatives. Graham and Rogers (2002) argue that ideally in order to identify a more precise picture of the companies' risk management practices one should compute the net position of the companies in the derivatives markets. However, as this information is only made available to a small number of firms, I opted to use the total gross notional value that is available to a larger number of companies. $^{7}$

I group foreign assets as any asset the company holds that earns the variation in the nominal exchange rate plus a premium during the period. These can be Treasury bonds (NTN-E), Central Bank bonds (NBC-E), assets invested in foreign banks, and cash in foreign currency.

\subsubsection{Sample Characteristics}

A summary of the statistics for the main variables in this paper can be found in Table 1 . Table 1 reports that although the number of exporters is stable during the period, the ratio of foreign sales to total sales follows a different pattern. During the fixed exchange rate regime, there was a slight reduction in the ratio of foreign sales to total sales; this path is inverted after the currency was let to float, when the ratio increased steadily. This fact corroborates the idea that the traditional expenditure-switching effect took place after the devaluation of the domestic currency, leading the ratio of foreign sales to total sales to rise.

Table 1 displays the behavior of corporate foreign borrowing during the period. It reports that the proportion of companies that hold foreign currency denominated debt increased under the fixed exchange rate regime reaching its peak in 1998. After 1999, under the floating regime, and especially after 2002, the number of companies that hold foreign currency debt decreased quickly, reaching its lowest value in 2006. Yet, the ratio of foreign debt to total debt increased between 1996 and 1999, but from the crisis until 2002 it was kept nearly stable. After 2002, this ratio decreased steadily, also reaching its minimum value in 2006.

Schneider and Tornell (2003) and Bris and Koskinen (2002) emphasize the interaction between government guarantees and asymmetries in sectoral behavior. Schneider and Tornell (2003) highlight the dichotomy between tradables and non-tradables. In their model, given the presence of bailout guarantees and the inability of the non-tradable sector to make a clear commitment to the repayment of its debt, currency mismatches arise endogenously, since foreign creditors would extend credit to the non-tradable sector. This currency mismatch would lead to a self-fulfilling crisis. Again, if there were no guarantees, managers would have no incentive to create currency mismatches. In the presence of bankruptcy costs, they would prefer to hedge the exchange rate risk. The authors show that under the fixed regime, firms in the non-tradable sector can grow faster by relaxing their borrowing constraints, but in the event of a depreciation, these companies will suffer heavily from balance sheet problems. Bris and Koskinen (2002)

\footnotetext{
${ }^{7}$ This problem is minimized in the Brazilian case, given that most of the companies keep only one position in the derivatives markets, suggested by the fact that swaps are the preferred derivative.
} 
view the currency crisis as an attempt by the government to rescue exporters, given their high leverage and low profitability under the fixed exchange rate regime. Their argument rests on the fact that it is optimal for the government to save exports by allowing the currency to float since it wants to boost investment in the economy. The depreciation would increase the profitability of the exporter sector by increasing their revenues in foreign currency and lowering their costs in domestic currency.

Table 1 shows that exporters and companies in the tradable sector hold a higher proportion of foreign currency denominated debt to total debt than non-exporters or non-tradable companies through all years of the sample, however it is possible to observe different paths across different periods. Exporters and non-tradable sector if not reduced kept their ratio of foreign debt to total debt stable during the period of the fixed exchange rate regime. Yet, non-exporters and firms in the non-tradeables sector increased their foreign leverage during the same period.

Table 1 also shows that independently of the sector classification of the firm the ratio of foreign debt to total debt decreased from 1999 to 2006. Again, it is possible to note sectoral differences in this path especially in the behavior of the exporter and non-exporter sectors. Exporters first increased their ratio of foreign currency debt to total debt until 2002, and then they decreased their ratio. On contrary, non-exporters start to lower their ratio of foreign debt to total debt right after the adoption of the floating exchange rate regime. Interesting to note that in 2006 the ratio of foreign debt to total debt for exporter is $23.7 \%$ lower than their ratio in 1999 , but it is $56.8 \%$ lower for non-exporters, indicating that nonexporters perform a greater effort in order to reduce their debt denominated in foreign currency.

The data about companies' ratio of total foreign debt to total debt presented in table 1 must be scrutinized carefully, as it may be misleading to analyze the exposure of the liability side of companies' balance sheets since it does not consider companies' use of currency derivatives. Companies with higher levels of foreign currency debt might choose to hedge their foreign positions, leading these companies to have a low degree of foreign exposure.

The results in table 1 indicates that once we consider only companies' unhedged debt or the (net) ratio of total foreign currency debt to total debt, we observe that the ratio reached its peak on 1997 under the fixed regime and it decreases steadily after that.

The results from Table 1 also shows that exporters and the tradable sector hold higher levels of unhedged positions than non-exporters and firms in the non-tradable sector and confirms the differences in behavior across different sectors. Corroborating previous results, the results in table 1 indicates that non-exporters and non-tradable sectors increased their unhedged foreign currency debt during the fixed exchange rate regime and reduced their unhedged positions after the adoption of a floating regime. Yet, different patterns arise when the behavior of exporters and tradable sectors is analyzed. The ratio of (net) total foreign debt to total debt increases from 1996 to 1997 for both sectors, and except for 1999 it decreases steadily afterwards. Again, in 2006, the ratio is almost a third of the ratio right before the crisis, which is a more acute reduction than in the tradable/exporter sectors. These results are consistent with Schneider and Tornell (2003) about the existence of an interaction between implicit guarantees associated to fixed exchange rate regimes and the non-tradable sector. Moreover, these results are consistent with the possibility that the exchange rate regime would have an impact on companies' currency mismatches. The data evidences that the floating exchange rate regime reduces the currency mismatches on companies' balance sheets.

Table 1 reports that the use of currency derivatives vary considerably from 1996 to 2006. The Table shows that the number of users of derivatives increased from 1996 to 2002 and indicates a slim reduction from 2002 to 2006. Likewise, the extent of the use of derivatives represented by the ratios of the total notional amount of derivatives to total assets also had a similar pattern during the same time frame. This evidence contradicts Eichengreen and Hausmann (1999) who assert the possibility that an increasing in the volatility of the exchange rate would lead to higher costs of hedging. They argue that one could observe less, not more hedging when exchange rates are less stable. Finally, table 1 shows that the ratio of total notional amount of derivatives to total foreign currency debt increased from 5.92\% in 1996 to 45.9\% in 2006, indicating that Brazilian firms indeed dispended an effort to reduce their foreign exposure during the period. 
This paper studies the relationship between the exchange rate regime and companies' foreign currency borrowing and the use of currency derivatives but in the period of study there are other factors that have an impact on companies' financial policies that we need to control for these variables in order to correctly identify the impact of the exchange rate regime.

Although there is no explicit model that explains the choice between foreign and domestic debt, the literature of corporate finance gives some guidance. Table 2 summarizes the statistics for the main cross-section determinants of companies' choice of the currency composition of the debt. Size seems to matter for companies' choice between domestic and foreign currency debt. Results in Table 2 demonstrate that larger firms hold higher levels of foreign debt. Allayannis, Weston and Klapper (2003) argue that this result can be viewed as evidence in favor of the market depth hypothesis. If domestic financial markets are not deep enough to satisfy companies' demand for funds, and if size is a good proxy for the probability of companies exhaust lending in domestic markets, one should expect larger firms to borrow more from abroad. This possibility is confirmed by the data.

Risk management variables are also important determinants of the currency composition of the debt. Companies with higher ratio of foreign sales to total sales and companies with foreign subsidiaries hold higher levels of foreign currency denominated debt. This corroborates with the idea that firms with natural hedges can afford hold higher levels of foreign currency denominated debt since these companies are more likely to benefit from depreciations of the home currency. Similar results are found for foreign assets and companies with subsidiaries abroad.

Investment opportunities represented by the market-to-book ratio appears not to be important to the determination of the currency composition of the debt. Although the results indicate that in 2000 and 2005 companies with higher ratio of market-to-book hold higher levels of foreign currency denominated debt this result is not robust across different periods. In addition, the results in Table 2 contradict Jeanne (2000) where more profitable firms would use foreign debt to signal their types. Profitability proxied by companies' gross margin is not statistically different between debtors and non-debtors for most of the years in the sample.

The results in Table 2 also show that companies' access to international capital markets is an important determinant in their choice between domestic and foreign currency debt. Foreign firms and firms that have issued ADR (American depository receipts) hold higher levels of foreign currency denominated debt since these companies have better access to borrow from abroad, due to the fact that would be easier to lenders to acquire information about them..

Finally, table 2 indicates that liquidity is also a determinant of companies’ foreign borrowing. More liquid firms, i.e. with higher ratio of current assets to current liabilities hold higher levels of foreign currency debt, even though this result is not robust for all years in the sample.

Table 3 reports summary statistics for the comparison between users and non-users of currency derivatives. Although Table 3 like Table 2 does not show any causal relationship, it helps to clarify the differences between foreign currency derivative users and non-users and allow to analyze other determinants of the use of foreign currency derivatives that not the exchange rate regime.

Companies can use foreign assets as substitutes for or complements to the use of derivatives. Table 3 suggests that Brazilian companies see foreign assets as a complement to the use of derivatives; derivatives users have higher ratios of foreign assets to total assets than non-users.

The corporate finance literature states that the relationship between the use of derivatives and size of the company is ambiguous. If fixed costs of hedging are important, one would expect large companies to hedge more than small firms. In opposition, if small firms are more constrained, therefore more dependent on their internal funds, they would hedge more in order to avoid fluctuations in their cash flow. Table 3 shows that users of currency derivatives are larger than non-users, confirming the existence of fixed costs of hedging.

Table 3 also supports the idea that companies use currency derivatives to reduce their foreign exposure. Companies with higher ratios of foreign sales to total sales, firms that have foreign operations, and those with higher levels of foreign debt to total debt are more likely to use currency derivatives. Interesting to note that only the last variable - the ratio of foreign debt to total debt - is robust across all years in the sample. 
If firms want to hedge in order to mitigate the underinvestment problem, theory says that firms with higher growth opportunities would hedge more. Table 3 shows that this pattern is not robust in the data. There is no systematic relationship between investment opportunities measured by the market-tobook ratio and the use of derivatives. Only for 2000, 2004 and 2005 the test does not reject the hypothesis that the mean of the market-to-book ratio is higher for users of currency derivatives.

Nance, Smith and Smithson (1993) argue that firms keep more liquid assets make less intense use of currency derivatives, since they will be more able to offset variations in their cash flow without using derivatives. The data confirms partially these results. Except for the period between 2001 and 2003, when the results in table 3 confirms that non-users are more liquid than users, in all other years, there is no statistical significance between users and non-users of currency derivatives with respect to their liquidity.

Smith and Stulz (1985) assert that given a convex corporate tax system, by reducing the variability of the cash flow, hedging would reduce the companies' tax liability, leading to an increase in the post-tax value of the firms. Therefore, it would be optimal for firms to hedge. They also show that hedging would reduce the expected bankruptcy costs, increasing the expected payoff to the firms' claimholders; thus, hedging would raise the companies' value by reducing the variability of their future cash flow. The results reported in Table 3 confirm that firms use currency derivatives in order to reduce their expected bankruptcy costs. Derivative users have higher ratio of debt to assets. Table 3 also shows that there is no evidence that firms use currency derivatives due to taxation. There is no clear relationship between the ratio of tax loss carry-forward to total assets and the use of currency derivatives.

\section{Corporate Financial Policies and the Exchange Rate Regime}

In this section, I analyze the determinants of companies' financial policies and among these I study whether the exchange rate regime played a role in the determination of companies' foreign currency borrowing, the use of derivatives and the currency mismatches of their balance sheets. I use the following empirical specification:

$Y_{i, t}=\alpha_{i}+\lambda_{t}+\beta$. Flexible $+\delta$.Foreign Sales $+\varphi .($ Foreign Sales $/$ Total Sales $) *$ Flexible $+X_{i, t}^{\prime} \cdot \gamma+\varepsilon_{i, t}$

Where $Y_{i, t}$ is one of three dependent variables: the ratio of total foreign debt to total debt, the ratio of (net) total foreign debt to total debt and the ratio of total amount of currency derivatives to total assets. ${ }^{8} \alpha_{i}$ represents a firm (sector) - specific effect , $\lambda_{t}$ is a series of time-dummies and $X_{i, t}^{\prime}$ is a set of explanatory variables with which I try to discriminate among different theories about the determination of the currency composition of companies' debt and the use of currency derivatives besides the exchange rate regime.

The inclusion of time-dummies in the specification allows for control of not only for differences across firms that are not captured by the explanatory variables but also the effect of the change on the macroeconomic environment that took place during the period. For example, Cowan, Hansen and Herrera (2005) argue that together with the change in the exchange rate regime there is a compression of the spread between domestic and foreign interest rates, leading to a higher level of domestic liabilities, we expect to control for this fact by adding year dummies to the estimation of (1). ${ }^{9}$

The specification in (1) tries to capture two possible impacts of the exchange rate regime. Flexible is a dummy variable that assumes the value 1 during the period under the flexible exchange rate regime (2000-2006). It captures the effect of the exchange rate regime on the level of corporate financial policies. We expect $\beta$ to be negative with respect to the companies' foreign borrowing and to be positive to the use of derivatives since a floating exchange rate regime would induce an improvement of companies' risk management practices. Second, as discussed by Schneider and Tornell (2003), the flexible exchange rate regime would induce companies' to match the currency composition of their assets with their liabilities; therefore, one can expect the level of companies' foreign currency liabilities to be more linked to their foreign revenue under a floating exchange rate regime since companies' would attempt to reduce the currency mismatches on their balance sheets. Therefore, we expect the coefficient of the interaction

\footnotetext{
${ }^{8}$ Similar results were found using the ratio of total amount of derivatives to total foreign debt.

${ }^{9}$ Instead of time-dummies, a specification using the spread between domestic and foreign interest rates was also estimated. The results are unchanged.
} 
between the flexible exchange rate regime and the ratio of foreign sales to total sales to be positive. In addition, we expect exporters to be less active on the use of currency derivatives under a flexible exchange rate regime because these are the companies more likely to benefit from depreciations of the home currency and they do attain foreign revenue to protect themselves from the negative impact of exchange rate fluctuations on their foreign currency liabilities. Therefore, when we analyze the determinants of the use of currency derivatives we expect the coefficient on the interaction variable to be negative.

\subsection{Results}

The results for estimation of (1) can be found in Table 4. The first striking result shown in Table 4 is that the exchange rate regime plays an important role on the determination of companies' financial policies, confirming the hypothesis that the flexible exchange rate regime leads companies to improve their risk management practices. Table 4 reports that there is a negative and statistically significant relationship between both proxies of companies' foreign currency liabilities and the flexible exchange rate regime. In addition, the results also indicate a positive and statistically significant impact of the flexible exchange rate regime on the use of currency derivatives.

Results in table 4 also confirm that after the adoption of a floating exchange rate regime companies try to match the currency composition of their assets and liabilities. The interaction between the ratio of foreign sales to total sales and the flexible regime dummy is positive and significant in all specifications for both proxies of companies' foreign exposure of their liability side. Therefore, under the floating regime, the companies that are more prepared to offset the negative effect of exchange rate fluctuations on their foreign liabilities, are exactly the companies that keep more unhedged positions, indicated by the increase in the importance of the ratio of foreign sales to total sales.

The results shown in table 4 with respect to the determinants of the use of currency derivatives confirm the role of foreign revenues in hedging negative impacts on companies' liabilities and the attempt by the companies under the floating regime in matching the currency composition of assets and liabilities. The results indicate a negative relationship between the use of currency derivatives and the interaction variable. This result can be explained by the fact that foreign revenues exert the role of substitute for financial derivatives by protecting companies from fluctuations of the exchange rate and as the importance of foreign revenue increases after the adoption of the floating regime, exporters will use less intensively currency derivatives. Moreover, the non-tradeable sector will use more intensively currency derivatives to protect themselves from changes in the exchange rate.

These results corroborate with the implicit guarantees theory that the fixed exchange rate regime biases corporate borrowing towards foreign currency denominated debt and that the floating exchange rate regime induces companies to take measures to reduce their exchange rate risk.

Following the corporate finance literature, Table 4 also analyzes the main cross-sectional determinants of companies' financial policies. The results show that size represented by the logarithm of companies' total sales matters with respect to the determination of corporate financial policies. Larger firms have higher ratios of total foreign currency denominated debt to total debt and higher ratios of derivatives to total assets. In addition, they are able to keep more unhedged positions. These results confirm the market depth hypotheses that domestic financial markets are not deep enough to fulfill the financial needs of larger firms and indicate the existence of fixed costs of hedging. The fact that there is a positive relationship between size and currency mismatches might indicate that larger firms perceive a higher probability of receiving bailouts in case of a crisis, deciding then to keep more unhedged positions.

The results in table 4 also corroborate the importance of other operational hedgings. Companies with higher ratio of foreign assets to total assets and companies with foreign subsidiaries borrow more in foreign currency and keep more unhedged positions. Moreover, these hedgings, especially foreign assets, are seem as complement for financial hedging indicated by the positive relationship between the use of derivatives and the ratio of foreign assets to total assets.

Results in table 4 point out that the access to financial markets proxied by the ownership ADR dummy seem to matter for foreign currency borrowing but not for the determination of companies' unhedged positions. Foreign firms and companies that issued ADR hold higher ratios of foreign debt to 
total debt, but these variables are not significant determinants of companies' ratio of (net) total foreign debt to total debt.

Confirming the literature, companies' with higher growth opportunities hold lower levels of foreign debt and use more intensively currency derivatives. The results in Table 4 also confirm the hypothesis that more profitable firms borrow more in foreign currency in order to signal their types as argued by Jeanne (2000). This evidence is provided by the positive relationship between companies' gross margin and both ratios of foreign currency denominated debt.

The results show that the ratio of foreign debt to total debt is a significant determinant of the extent of companies' use of currency derivatives. This corroborates the idea that Brazilian companies use currency derivatives in order to reduce the exposure of their balance sheets to fluctuations of the exchange rate and not for speculative reason. Moreover, the positive impact of the ratio of debt-to-assets on companies' use of currency derivative confirms the hypothesis that companies hedge in order to avoid incurring in the costs of financial distress.

Finally, the results indicate that there is no relationship between the use of derivatives and taxation the results in table 4 show a negative relationship between liquidity and foreign currency borrowing and defying expectations a positive relationship between the use of currency derivatives and liquidity, indicating that liquidity is a complement and not a substitute for the use of currency derivatives.

\subsubsection{Robustness Exercises}

First, besides the interaction between the ratio of foreign sales to total sales and the flexible exchange rate regime dummy, we also included the interaction between all control variables and the flexible exchange rate regime dummy in order to control for other changes associated to the exchange rate regime that may be affect companies' financial policies. Results in table 4 confirm our previous results about the relationship between corporate financial policies and the exchange rate regime. Interesting to observe that the results (not shown) indicate that the interactions between the ratio of foreign assets to total assets with the exchange rate regime dummy is positive and statistically significant, showing also an increase in the importance of other types of hedgings on the companies' attempt to reduce their currency mismatches. Similar results were found by Kamil (2006) using a measure of companies' dollarization assets.

The results in table 4 are robust to different methods used in the estimation of (1). All endogenous variables comprehend variables between 0 and 1 , therefore we also perform the estimation of (1) using a Tobit specification. Results are shown in table 5. The results in table 5 corroborate that the flexible exchange rate regime have a negative impact on companies' foreign currency borrowing, a positive impact on the use of currency derivatives and improve the currency matching on companies' balance sheets. Considering the cross-sectional determinants, the result with respect to the importance of growth opportunities and profitability for the determination of the currency composition of companies' debt seem not to be robust. Similar result found for the impact of companies' liquidity on the use of currency derivatives. Equation (1) was also estimated using a panel estimator with fixed effects. The results (not shown) are also robust.

Table 6 shows the results for the estimation of the determinants of companies' financial policies by dividing the sample in two time-periods: one corresponding to the fixed exchange rate regime from 1996 to 1998, and other from 2000 to 2006 representing the flexible exchange rate regime. The results in table 6 indicate that under the fixed exchange rate regime foreign revenues do not play a role on companies' financial policies. There is no statistical significant relationship between the ratio of foreign sales to total sales and both proxies for companies' foreign currency liabilities and the use of currency derivatives. Opposing these results, under the floating exchange rate regime there is a positive relationship between both ratios of foreign debt and the ratio of foreign sales to total sales and a negative relationship between the ratio of derivatives to total assets and companies' foreign revenues, confirming that a change on corporate financial policies took place when we moved from the fixed to the floating exchange rate regime with companies' reducing the mismatches on their balance sheets.

Following Kamil (2006) we also use the semi-parametric procedure proposed by DiNardo, Lemieux and Fortin (1996) to estimate a counterfactual distribution of companies' ratio of foreign debt to 
total debt and (net) foreign debt to total debt. In this method, we analyze the impact of the exchange rate regime on the distribution of the companies' foreign currency liabilities given the cross-sectional characteristics under the fixed exchange rate regime. As explained by DiNardo, Lemieux and Fortin (1996), the method builds a counterfactual density that would have prevailed under the floating exchange rate regime if the characteristics of the firms remained as in the fixed exchange rate regime. Figure 1 presents the results. The results confirm that companies' reduce their total and unhedged debt denominated in foreign currency under the floating regime. Figure 1 shows that under the floating there is an increase in the proportion of the companies with lower ratio of foreign debt total debt and there is a significant reduction of the number of the companies with higher ratios of foreign currency debt to total debt, implying a negative impact of the flexible exchange rate regime on the average ratio of foreign debt to total debt. Figure 1 also shows that these results are robust to the use of the ratio of (net) foreign debt to total debt, indicating a negative impact of the flexible regime on companies' ratio of unhedged foreign debt to total debt.

One question levied by the literature is whether this reduction in companies' currency mismatches takes place homogeneously for all levels of exchange rate risk or companies' that face higher exchange rate risk observe a more pronounced reduction in their foreign liabilities and a higher effort to match their assets and liabilities. We answer this question using a conditional quantile estimator. Results in table 7 confirm that the impact of the exchange rate regime is higher for companies in the highest quantiles of exchange rate risk. Similar that the results found for Kamil (2006), the results in table 7 indicate almost a monotonic increase in the impact of the flexible regime for companies with higher ratios of foreign currency debt. In these companies, the adoption of the flexible exchange rate regime not only reduce more substantially the average level of foreign debt but also leads to an increase in the degree of currency match on their balance sheets.

\section{Conclusion}

This paper studies the relationship between the exchange rate regime and companies' financial policies for a sample of non-financial Brazilian companies from 1996 to 2006. We find that the exchange rate regime plays an important role in the determination of companies' financial policies. The results are consistent with the hypothesis that the floating exchange rate regime reduces companies' external vulnerability by leading them to take measures against their exchange rate risk and that the fixed exchange rate regime biases corporate borrowing towards foreign currency denominated debt. I show that the floating exchange rate regime exerts a negative impact on companies' foreign borrowing and a positive effect on the use of currency derivatives. In addition, the results indicate that the floating regime induces companies to lower the currency mismatches in their balance sheets. These results are robust to the method of estimation and inclusion of control variables. Moreover, the paper shows that this reduction in companies' currency mismatches is more pronounced for companies in the highest quantiles of exchange rate risk; therefore, for companies with highest vulnerability to fluctuation in the exchange rate.

The results of this analysis indicate that the exchange rate regime is a significant determinant of countries' external vulnerability since it plays an important role on companies' financial policies. This is a contrast to the assertions made by Eichengreen and Hausmann (1999) or Calvo and Mishkin (2003) that the choice of the exchange rate regime is of second order importance in determining countries' external vulnerability. This paper provides evidence that the floating regime can mitigate the problem of the "original sin" by leading companies to reduce their exchange rate exposure, by reducing the currency mismatches on their balance sheets. Such action corroborates Goldstein and Turner (2004) who argue that there might be a relationship between currency mismatches and the exchange rate regime.

It is important to emphasize that vulnerabilities remain, and governments should carry out additional economic reforms in order to improve countries' institutions. However, as this paper indicates, the adoption of a floating exchange rate regime by emerging markets like Brazil, indeed leads companies to be more aware of the risk of keeping unhedged positions, reducing the possibility of huge economic downturns. Thus, even if the choice of the exchange rate might not be the primary solution for the reduction of countries' external vulnerability, it is clearly an integral part of the solution toward beneficial economic reforms. 


\section{Appendix \\ Description of Variables}

Derivatives - Total notational amount of currency derivatives. It includes swaps, options, forwards, and futures. It is reported in companies' annual reports under the item financial instruments.

Total Assets - Book value of companies’assets.

ADR - Dummy variable assumes the value of 1 if the company issues American depositary receipts and 0 otherwise.

Total Foreign Debt - Total foreign currency denominated Debt reported by companies' reports under the item loans and financing.

Total Debt - Total amount of company's Debt. It is a sum in Reais of domestic and foreign currency denominated debt.

(Net) Foreign Debt - Total foreign debt minus the total notional amount of currency derivatives expressed in Reais.

Foreign Assets - The total amount of assets the company holds that earn the variation in the nominal exchange rate plus a premium during the period. These can be Treasury bonds (NTN-E), Central Bank bonds (NBC-E), assets invested in foreign banks, and cash in foreign currency.

Foreign Sales - sales in US $\$$ converted to Reais by the exchange rate at the end of the year.

Total Sales - Total gross sales expressed in Reais.

Foreign Operations - Dummy variable assumes the value 1 if the company has foreign production subsidiaries.

Gross Margin - Total calculated EBIT divided by total sales.

Market-to-Book - Market Value of Equity divided by net worth.

Size - The logarithm of total gross sales in Reais converted to US\$ by the exchange rate at the end of the year.

Ownership - Dummy variable that assumes the value 1 if the firm is owned by domestic agents and 0 otherwise.

Current ratio - Current assets divided by current liabilities.

Debt-to-Assets - Total debt divided by companies’ total assets.

Tax loss Carried Forward / Total Assets - The ratio of companies' tax losses carried forward divided by total assets. 


\section{REFERENCES}

Allayannis, G., Weston, J., and Klapper, L., 2003, Capital structure and financial risk: Evidence from foreign debt use in East Asia, The Journal of Finance 58, 2667-2709.

Bris, A. and Koskinen,Y., 2002, Corporate Leverage and Currency crises, Journal of Financial Economics 63, 275-310.

Burnside, C., Eichembaum, M. and Rebelo, S., 2001, Hedging and Financial Fragility in fixed Exchange Rate Regimes, European Economic Review 45, 1151-1193.

Calvo, G. and Mishkin, F., 2003, The Mirage of Exchange Rate Regimes for Emerging Market Countries, The Journal of Economic Perspectives 17, 99-118.

Calvo, G. and Reinhardt, C., 2002, Fear of Floating, The quarterly Journal of economics 67, 379-408.

Cowan, K., Hansen, E.and Herrera, L., 2005, Currency mismatches, balance-sheet effects and hedging in Chilean non-financial corporations, IADB Working Paper 521.

DiNardo, J., Lemieux, T. and Fortin, J., 1996, Labor market institutions, and the distribution of wages, 1973-1992: a semi-parametric approach, Econometrica 64, 1001-1046.

Dooley, M., 2000, A model of crises in emerging markets, The Economic Journal 110, 256-272.

Eichengreen, B., and Hausmann, R., 1999, Exchange rates and Financial fragility, NBER working paper 7418.

Goldstein, M. and Turner, P., 2004, Controlling Currency Mismatches in Emerging Markets, Institute for International Economics, 1st edition.

Graham, J. and Rogers, D., 2002, Do firms hedge in response to tax incentives?, The Journal of Finance 57, 815-839.

Jeanne, O., 2000, Foreign currency debt and the global financial architecture, European Economic Review 44, 153-161.

Kamil, H., 2006, Does moving to a flexible exchange rate regime reduce currency mismatches in firms' balance sheets?, IMF Working paper.

Martinez, L. and Werner, A., 2002, The exchange rate regime and the currency composition of corporate debt: The Mexican experience, Journal of Development Economies 69, 315-334.

Nance, D., Smith, C., and Smithson, C., 1993, On the Determinants of Corporate hedging, The Journal of Finance 48, 267-284.

Rossi, J., 2007, Foreign currency denominated debt and the exchange rate regime, Pesquisa e Planejamento Econômico 37, pp.1-20.

Schneider, M. and Tornell, A., 2003, Balance sheet effects, bailout guarantees and financial crises, Review of Economic Studies 71, 883-913.

Smith, C. and Stulz, R., 1985, The Determinants of firms' Hedging Policies, Journal of Financial and Quantitative Analysis 20, 391-405. 
Table 1 - Summary Statistics

Table 1 shows the summary of the statistics of the variables used in the analysis. The description of all variables is in the appendix.

\begin{tabular}{|c|c|c|c|c|c|c|c|c|c|c|c|}
\hline & 1996 & 1997 & 1998 & 1999 & 2000 & 2001 & 2002 & 2003 & 2004 & 2005 & 2006 \\
\hline Number of firms & 180 & 180 & 180 & 180 & 180 & 180 & 180 & 180 & 180 & 180 & 180 \\
\hline Exporters (\%) & 54.9 & 54.3 & 56.1 & 56.1 & 56.6 & 56.6 & 56.6 & 56.6 & 56.1 & 54.9 & 54.9 \\
\hline Foreign Sales / Total Sales (\%) & 10.9 & 10.8 & 10.5 & 12.5 & 13.2 & 14.4 & 14.4 & 14.6 & 14.8 & 14.8 & 14.8 \\
\hline Debtors (\%) & 77.5 & 78.0 & 82.6 & 79.2 & 78.0 & 78.6 & 78.6 & 74.6 & 73.4 & 72.2 & 65.3 \\
\hline Total Foreign Debt / Total Debt (\%) & 42.7 & 44.3 & 44.3 & 47.1 & 46.9 & 46.9 & 47.3 & 40.9 & 38.4 & 33.5 & 30.3 \\
\hline Exporters & 51.1 & 52.2 & 49.2 & 53.9 & 54.9 & 54.5 & 56.5 & 48.6 & 48.4 & 44.7 & 41.1 \\
\hline Non-Exporters & 32.8 & 35.3 & 38.3 & 38.6 & 36.6 & 37.0 & 35.6 & 30.7 & 25.9 & 20.1 & 16.8 \\
\hline Tradeables & 46.9 & 49.2 & 47.8 & 52.5 & 51.1 & 49.5 & 51.2 & 43.5 & 41.5 & 37.6 & 33.9 \\
\hline Non-Tradeables & 32.1 & 32.3 & 35.6 & 34.3 & 36.7 & 40.8 & 38.1 & 34.4 & 31.2 & 23.6 & 21.3 \\
\hline (Net) Foreign Debt / Total Debt (\%) & 40.9 & 42.6 & 40.9 & 43.5 & 41.8 & 36.9 & 35.0 & 31.3 & 29.6 & 24.8 & 22.7 \\
\hline Exporters & 48.9 & 50.2 & 45.7 & 50.8 & 50.5 & 46.6 & 44.2 & 37.8 & 39.3 & 36.5 & 31.8 \\
\hline Non-Exporters & 31.6 & 33.8 & 35.1 & 34.5 & 30.8 & 24.4 & 23.4 & 22.8 & 17.4 & 11.7 & 11.0 \\
\hline Tradable & 44.6 & 47.0 & 43.6 & 48.6 & 46.2 & 41.5 & 39.0 & 34.2 & 33.8 & 30.4 & 26.8 \\
\hline Non-Tradable & 31.6 & 31.7 & 34.2 & 31.7 & 31.3 & 26.0 & 25.8 & 24.2 & 19.7 & 13.2 & 11.5 \\
\hline Users of Derivatives (\%) & 6.94 & 8.67 & 13.9 & 16.2 & 24.3 & 34.7 & 38.7 & 36.4 & 34.1 & 35.8 & 35.4 \\
\hline Derivatives / Total Assets (\%) & 0.51 & 0.53 & 0.94 & 1.22 & 1.68 & 3.08 & 4.13 & 3.22 & 2.33 & 2.55 & 1.79 \\
\hline Derivatives / Total Foreign Debt & 5.92 & 3.51 & 6.70 & 7.24 & 14.3 & 19.8 & 26.3 & 24.5 & 35.2 & 53.5 & 45.9 \\
\hline
\end{tabular}


Table 2 - Summary Statistics - Foreign Currency Debtors

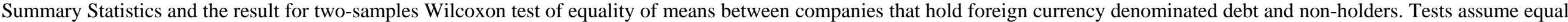

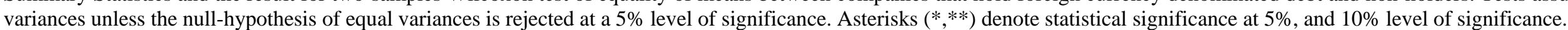

\begin{tabular}{|c|c|c|c|c|c|c|c|c|c|c|c|c|}
\hline Variable/Year & Debtor & 1996 & 1997 & 1998 & 1999 & 2000 & 2001 & 2002 & 2003 & 2004 & 2005 & 2006 \\
\hline \multirow{2}{*}{ Foreign Debt / Total Debt } & No & 0 & 0 & 0 & 0 & 0 & 0 & 0 & 0 & 0 & 0 & 0 \\
\hline & Yes & 54.8 & 57.3 & 55.1 & 59.8 & 60.0 & 59.7 & 59.6 & 54.0 & 51.5 & 46.1 & 45.9 \\
\hline \multirow{2}{*}{ Foreign Sales / Total Sales (\%) } & No & 4.82 & 5.83 & 6.29 & 7.47 & 6.43 & 6.48 & 5.89 & 5.87 & 8.13 & 6.42 & 7.13 \\
\hline & Yes & $12.9 *$ & $12.5^{*}$ & $12.0 * *$ & $14.1^{*}$ & $14.6^{*}$ & $15.2^{*}$ & $17.0^{*}$ & $17.6^{*}$ & $16.9 *$ & $17.5^{*}$ & $18.8^{*}$ \\
\hline \multirow{2}{*}{ Foreign Assets / Total Assets (\%) } & No & 0 & 0 & 0 & 0 & 0 & 0 & 0 & 0 & 0.01 & 0.04 & 0.01 \\
\hline & Yes & $0.22 *$ & $0.35 *$ & $0.99 *$ & $1.36^{*}$ & $1.83^{*}$ & $2.02 *$ & $2.26 *$ & $1.74 *$ & $1.98^{*}$ & $2.27^{*}$ & $1.66^{*}$ \\
\hline \multirow{2}{*}{ Foreign Operations Dummy } & No & 0.022 & 0.044 & 0.027 & 0.046 & 0.066 & 0.045 & 0.000 & 0.000 & 0.019 & 0.018 & 0.046 \\
\hline & Yes & $0.216^{*}$ & $0.200 *$ & $0.196^{*}$ & $0.197^{*}$ & $0.193^{*}$ & $0.198 *$ & $0.213^{*}$ & $0.225^{*}$ & $0.225^{*}$ & $0.228^{*}$ & $0.239 *$ \\
\hline \multirow{2}{*}{ Size (Total Sales) in R $\$$ millions } & No & 127.8 & 127.9 & 122.6 & 118.7 & 127.7 & 159.6 & 212.9 & 273.4 & 233.2 & 342.2 & 476.9 \\
\hline & Yes & $1052 *$ & $1125^{*}$ & $1177 *$ & $1462 *$ & $1975 *$ & $2354 *$ & $2747 *$ & $3637 *$ & $4494 *$ & $5146^{*}$ & $6518^{*}$ \\
\hline \multirow{2}{*}{ Ownership } & No & $0.98^{*}$ & $0.98^{*}$ & $0.98^{*}$ & $0.98 *$ & $0.98^{*}$ & $0.95 *$ & $0.98^{*}$ & $0.95 *$ & $0.98 *$ & $0.98 *$ & 0.89 \\
\hline & Yes & 0.87 & 0.87 & 0.85 & 0.81 & 0.81 & 0.81 & 0.80 & 0.80 & 0.80 & 0.79 & 0.80 \\
\hline \multirow{2}{*}{ ADR } & No & 0 & 0 & 0 & 0 & 0 & 0 & 0 & 0.021 & 0 & 0.021 & 0.021 \\
\hline & Yes & $0.12 *$ & $0.15^{*}$ & $0.15^{*}$ & $0.18^{*}$ & $0.22 *$ & $0.22 *$ & $0.25^{*}$ & $0.25^{*}$ & $0.25^{*}$ & $0.25 *$ & $0.29 *$ \\
\hline \multirow{2}{*}{ Market-to-Book } & No & 0.87 & 0.63 & 1.34 & 1.59 & 0.73 & 0.80 & 0.61 & 2.38 & 1.32 & 1.45 & 2.45 \\
\hline & Yes & 0.84 & 0.77 & 0.89 & 1.18 & $0.96^{*}$ & 0.81 & 0.95 & 1.63 & 1.67 & $1.71^{* *}$ & 2.09 \\
\hline \multirow{2}{*}{ Gross Margin (\%) } & No & 8.98 & 10.6 & 12.5 & 15.5 & 11.4 & 11.2 & 11.5 & 9.13 & 8.20 & 7.25 & 8.39 \\
\hline & Yes & 8.66 & 9.59 & 9.18 & 12.6 & 12.8 & 13.1 & 13.1 & 12.2 & $13.3^{*}$ & $12.1^{*}$ & $12.3^{*}$ \\
\hline \multirow{2}{*}{ Current Ratio } & No & 1.11 & 0.93 & 0.73 & 0.80 & 0.95 & 0.90 & 0.95 & 0.92 & 0.85 & 0.80 & 0.88 \\
\hline & Yes & 1.29 & 1.34 & $1.29 *$ & $1.29 *$ & 1.37 & 1.31 & 1.29 & $1.29 * *$ & $1.43^{*}$ & $1.50^{*}$ & $1.63^{*}$ \\
\hline
\end{tabular}


Table 3 - Summary Statistics Foreign Currency Derivative Users

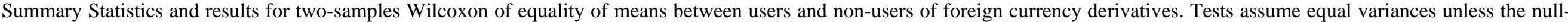
hypothesis of equal variances is rejected at a $5 \%$ level of significance. Asterisks $(*, * *)$ denote statistical significance at $5 \%$, and $10 \%$ level of significance.

\begin{tabular}{|c|c|c|c|c|c|c|c|c|c|c|c|c|}
\hline Variable/Year & & 1996 & 1997 & 1998 & 1999 & 2000 & 2001 & 2002 & 2003 & 2004 & 2005 & 2006 \\
\hline \multirow{2}{*}{ Derivatives / Total Assets (\%) } & No & 0 & 0 & 0 & 0 & 0 & 0 & 0 & 0 & 0 & 0 & 0 \\
\hline & User & 7.68 & 6.33 & 7.07 & 7.84 & 7.19 & 9.25 & 11.1 & 9.20 & 7.12 & 7.42 & 6.89 \\
\hline \multirow{2}{*}{ Foreign Assets / Total Assets (\%) } & No & 0.07 & 0.09 & 0.31 & 0.62 & 0.85 & 1.07 & 0.93 & 0.61 & 0.91 & 0.65 & 0.26 \\
\hline & User & 1.39 & 2.19 & $3.92 * *$ & $3.29 * *$ & $3.10^{*}$ & 2.45 & $3.02 *$ & $2.45^{*}$ & $2.59 *$ & $3.76^{*}$ & $3.42 *$ \\
\hline \multirow{2}{*}{ Size (Total Sales) in R\$ Millions } & No & 732 & 807 & 824 & 971 & 1155 & 1371 & 1706 & 1971 & 2033 & 2748 & 3102 \\
\hline & User & 1732 & 1775 & $1730^{*}$ & $1938 *$ & $2568 *$ & 2540 & 2689 & 3805 & $5034 *$ & 5632 & $6712^{*}$ \\
\hline \multirow{2}{*}{ Foreign Sales / Total Sales } & No & 9.92 & 9.76 & 9.95 & 11.5 & 11.5 & 11.2 & 11.9 & 12.5 & 12.9 & 12.3 & 12.5 \\
\hline & User & 24.2 & $22.6 * *$ & 16.9 & 18.0 & 16.2 & $17.2^{* *}$ & $18.4^{*}$ & 17.7 & 17.6 & $18.2 * *$ & $20.5^{*}$ \\
\hline \multirow{2}{*}{ Foreign Operations Dummy } & No & 0.16 & 0.15 & 0.15 & 0.15 & 0.15 & 0.13 & 0.11 & 0.12 & 0.13 & 0.13 & 0.13 \\
\hline & User & 0.25 & 0.33 & 0.25 & 0.21 & 0.19 & $0.23 * *$ & $0.25 *$ & $0.24 * *$ & $0.24 * *$ & $0.24^{* *}$ & $0.30 *$ \\
\hline \multirow{2}{*}{ Foreign Debt / Total Debt } & No & 40.6 & 41.5 & 40.5 & 42.9 & 40.1 & 35.8 & 35.4 & 27.6 & 26.1 & 23.3 & 24.1 \\
\hline & User & $70.0^{*}$ & $73.5^{*}$ & $68.1^{*}$ & $68.8^{*}$ & $68.1^{*}$ & $67.9 *$ & $65.8^{*}$ & 63.8* & $62.1^{*}$ & $52.0^{*}$ & $47.3^{*}$ \\
\hline \multirow{2}{*}{ Market-to-Book } & No & 0.78 & 0.68 & 0.55 & 1.13 & 0.85 & 0.76 & 0.86 & 1.13 & 1.63 & 1.38 & 1.98 \\
\hline & User & 1.05 & 0.88 & 0.97 & 1.34 & $1.39 * *$ & 0.96 & 1.12 & 1.99 & $2.65^{* *}$ & $2.41^{*}$ & 2.85 \\
\hline \multirow{2}{*}{ Debt-to-Assets } & No & 0.19 & 0.21 & 0.22 & 0.24 & 0.23 & 0.22 & 0.25 & 0.23 & 0.24 & 0.25 & 0.24 \\
\hline & User & $0.30 *$ & $0.34 *$ & $0.34 *$ & $0.34 *$ & $0.30 *$ & $0.34 *$ & $0.38^{* *}$ & $0.36^{*}$ & 0.29 & 0.27 & 0.24 \\
\hline \multirow{2}{*}{ Tax Loss Carried Forward / Total Assets (\%) } & No & 0.17 & 0.11 & $0.49 *$ & 1.29 & 0.30 & 0.38 & 0.07 & 0.25 & 0.15 & 0.18 & 0.05 \\
\hline & User & 0.10 & 0.07 & 0.07 & 0.87 & 0.15 & 0.39 & 0.27 & 0.20 & 0.09 & 0.24 & 0.09 \\
\hline \multirow{2}{*}{ Current Ratio } & No & 1.51 & 2.41 & 1.51 & 1.41 & 1.58 & $1.65 *$ & $1.49 *$ & 1.49 & 1.52 & 1.52 & 1.59 \\
\hline & User & 1.32 & 1.28 & 1.36 & 1.41 & 1.34 & 1.14 & 1.19 & 1.27 & 1.42 & 1.58 & 1.67 \\
\hline
\end{tabular}


Table 4 - Results for the determinants of Corporate Financial Policies

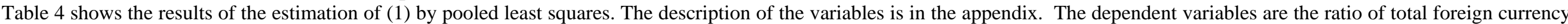

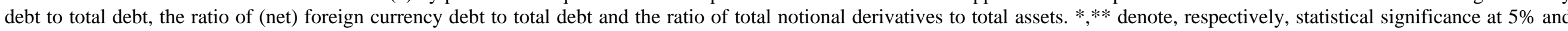
$10 \%$.

Foreign Debt / Total Debt

(Net) Foreign Debt / Total Debt

\begin{tabular}{|c|c|c|c|c|c|c|c|c|c|c|}
\hline Variable & Coeff. & Coeff. & Coeff. & Coeff. & Coeff. & Coeff. & Variable & Coeff. & Coeff. & Coeff. \\
\hline Flexible & $\begin{array}{l}-0.176 \\
(-5.84)^{*}\end{array}$ & $\begin{array}{c}-0.266 \\
(-10.71)^{*}\end{array}$ & $\begin{array}{l}-0.879 \\
(-11.34)^{*}\end{array}$ & $\begin{array}{l}-0.249 \\
(-7.43)^{*}\end{array}$ & $\begin{array}{c}-0.288 \\
(-9.37)^{*}\end{array}$ & $\begin{array}{c}-0.380 \\
(-11.0)^{*}\end{array}$ & Flexible & $\begin{array}{c}0.088 \\
(2.21)^{*}\end{array}$ & $\begin{array}{c}0.014 \\
(3.26)^{*}\end{array}$ & $\begin{array}{c}0.022 \\
(2.11)^{*}\end{array}$ \\
\hline Foreign Sales / Total Sales & $\begin{array}{c}0.298 \\
(4.33)^{*}\end{array}$ & $\begin{array}{l}0.058 \\
(1.06)\end{array}$ & $\begin{array}{l}0.026 \\
(0.45) \\
\end{array}$ & $\begin{array}{c}0.234 \\
(3.43)^{*}\end{array}$ & $\begin{array}{l}0.053 \\
(0.93) \\
\end{array}$ & $\begin{array}{l}0.048 \\
(0.76) \\
\end{array}$ & $\begin{array}{c}\text { Foreign Sales / Total } \\
\text { Sales }\end{array}$ & $\begin{array}{c}0.021 \\
(2.93)^{*}\end{array}$ & $\begin{array}{l}-0.037 \\
(-0.44) \\
\end{array}$ & $\begin{array}{l}0.092 \\
(0.11) \\
\end{array}$ \\
\hline $\begin{array}{l}\text { (Foreign Sales / Total } \\
\text { Sales)*Flexible }\end{array}$ & $\begin{array}{c}0.226 \\
(2.86)^{*}\end{array}$ & $\begin{array}{c}0.148 \\
(2.34)^{*}\end{array}$ & $\begin{array}{c}0.221 \\
(2.91)^{*}\end{array}$ & $\begin{array}{c}0.247 \\
(3.18)^{*}\end{array}$ & $\begin{array}{c}0.195 \\
(2.96)^{*}\end{array}$ & $\begin{array}{l}0.212 \\
(2.66)^{*}\end{array}$ & $\begin{array}{l}\text { (Foreign Sales / Total } \\
\text { Sales)*Flexible }\end{array}$ & $\begin{array}{c}-0.077 \\
(-2.08)^{*}\end{array}$ & $\begin{array}{c}-0.018 \\
(-1.82)^{* *}\end{array}$ & $\begin{array}{c}-0.031 \\
(-2.86)^{*}\end{array}$ \\
\hline Foreign Operations Dummy & & $\begin{array}{c}0.062 \\
(3.40)^{*}\end{array}$ & $\begin{array}{c}0.053 \\
(1.77)^{* *}\end{array}$ & & $\begin{array}{c}0.052 \\
(2.55)^{*}\end{array}$ & $\begin{array}{c}0.065 \\
(2.11)^{*}\end{array}$ & $\begin{array}{c}\text { Foreign Operations } \\
\text { Dummy }\end{array}$ & & $\begin{array}{l}0.020 \\
(0.54)\end{array}$ & $\begin{array}{l}0.015 \\
(0.39)\end{array}$ \\
\hline Foreign Assets / Total Assets & & $\begin{array}{c}0.821 \\
(5.52)^{*}\end{array}$ & $\begin{array}{c}1.17 \\
(4.16)^{*}\end{array}$ & & $\begin{array}{c}0.522 \\
(3.49)^{*}\end{array}$ & $\begin{array}{c}0.778 \\
(3.16)^{*}\end{array}$ & $\begin{array}{c}\text { Foreign Assets / Total } \\
\text { Assets }\end{array}$ & & $\begin{array}{c}0.154 \\
(3.51)^{*}\end{array}$ & $\begin{array}{c}0.200 \\
(2.45)^{*}\end{array}$ \\
\hline Size & & $\begin{array}{c}0.092 \\
(18.81)^{*}\end{array}$ & $\begin{array}{c}0.096 \\
(12.52)^{*}\end{array}$ & & $\begin{array}{c}0.076 \\
(15.02)^{*}\end{array}$ & $\begin{array}{c}0.091 \\
(11.90)^{*}\end{array}$ & $\begin{array}{c}\text { Foreign Debt / Total } \\
\text { Debt }\end{array}$ & & $\begin{array}{c}0.033 \\
(8.61)^{*}\end{array}$ & $\begin{array}{c}0.067 \\
(1.78)^{* *}\end{array}$ \\
\hline Ownership & & $\begin{array}{l}-0.076 \\
(-3.75)^{*}\end{array}$ & $\begin{array}{l}-0.029 \\
(-0.86)\end{array}$ & & $\begin{array}{l}-0.023 \\
(-1.14) \\
\end{array}$ & $\begin{array}{l}-0.040 \\
(-1.16) \\
\end{array}$ & Size & & $\begin{array}{c}0.047 \\
(4.43)^{*}\end{array}$ & $\begin{array}{c}0.044 \\
(4.18)^{*}\end{array}$ \\
\hline ADR & & $\begin{array}{c}0.034 \\
(1.81)^{* *}\end{array}$ & $\begin{array}{c}0.052 \\
(1.76)^{* *}\end{array}$ & & $\begin{array}{l}-0.011 \\
(-0.59)\end{array}$ & $\begin{array}{l}0.019 \\
(0.57) \\
\end{array}$ & Debt-to-Assets & & $\begin{array}{c}0.015 \\
(3.28)^{*}\end{array}$ & $\begin{array}{c}0.016 \\
(1.92)^{* *}\end{array}$ \\
\hline Market-to-book & & $\begin{array}{c}-0.013 \\
(-2.07)^{*}\end{array}$ & $\begin{array}{c}-0.025 \\
(-5.33)^{*}\end{array}$ & & $\begin{array}{c}-0.049 \\
(-9.14)^{*}\end{array}$ & $\begin{array}{c}-0.051 \\
(-16.67)^{*}\end{array}$ & Tax & & $\begin{array}{c}0.031 \\
(0.93) \\
\end{array}$ & $\begin{array}{l}-0.053 \\
(-0.58) \\
\end{array}$ \\
\hline Gross Margin & & $\begin{array}{l}0.0323 \\
(3.50)^{*}\end{array}$ & $\begin{array}{l}0.0273 \\
(2.88)^{*}\end{array}$ & & $\begin{array}{c}0.0187 \\
(1.57) \\
\end{array}$ & $\begin{array}{c}0.0165 \\
(1.40)\end{array}$ & Market-to-book & & $\begin{array}{c}0.014 \\
(9.85)^{*}\end{array}$ & $\begin{array}{c}0.013 \\
(3.44)^{*}\end{array}$ \\
\hline Current Ratio & & $\begin{array}{c}-0.010 \\
(-9.59)^{*}\end{array}$ & $\begin{array}{l}-0.010 \\
(-8.98)^{*}\end{array}$ & & $\begin{array}{c}-0.099 \\
(-9.12)^{*}\end{array}$ & $\begin{array}{c}-0.090 \\
(-8.91)^{*}\end{array}$ & Current Ratio & & $\begin{array}{c}0.063 \\
(4.19)^{*}\end{array}$ & $\begin{array}{l}0.0291 \\
(2.11)^{*}\end{array}$ \\
\hline Cross variables & No & No & Yes & No & No & Yes & Cross variables & No & No & Yes \\
\hline Sectoral Dummies & Yes & Yes & Yes & Yes & Yes & Yes & Sectoral Dummies & Yes & Yes & Yes \\
\hline Time Dummies & Yes & Yes & Yes & Yes & Yes & Yes & Time Dummies & Yes & Yes & Yes \\
\hline $\mathbf{N}$ & 1980 & 1980 & 1980 & 1980 & 1980 & 1980 & $\begin{array}{l}\mathbf{N} \\
\end{array}$ & 1980 & 1980 & 1980 \\
\hline $\mathbf{R 2}$ & 0.130 & 0.392 & 0.396 & 0.145 & 0.309 & 0.359 & $\mathbf{R 2}$ & 0.09 & 0.231 & 0.229 \\
\hline
\end{tabular}


Table 5 - Results for the determinants of Corporate Financial Policies

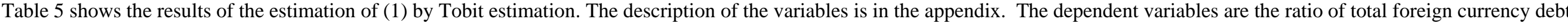

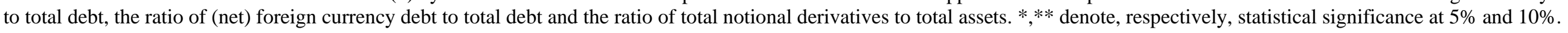

\begin{tabular}{|c|c|c|c|c|c|c|c|c|c|c|}
\hline \multirow[b]{2}{*}{ Variable } & \multicolumn{3}{|c|}{ Foreign Debt / Total Debt } & \multicolumn{3}{|c|}{ (Net) Foreign Debt / Total Debt } & \multicolumn{4}{|c|}{ Derivatives / Total Assets } \\
\hline & Coeff. & Coeff. & Coeff. & Coeff. & Coeff. & Coeff. & Variable & Coeff. & Coeff. & Coeff. \\
\hline Flexible & $\begin{array}{c}-0.274 \\
(-5.66)^{*}\end{array}$ & $\begin{array}{c}-0.334 \\
(-9.37)^{*}\end{array}$ & $\begin{array}{c}-0.155 \\
(-12.89) *\end{array}$ & $\begin{array}{c}-0.353 \\
(-7.27)^{*}\end{array}$ & $\begin{array}{c}-0.410 \\
(-10.61)^{*}\end{array}$ & $\begin{array}{c}-0.152 \\
(-11.66)^{*}\end{array}$ & Flexible & $\begin{array}{c}0.075 \\
(3.86)^{*}\end{array}$ & $\begin{array}{c}0.087 \\
(3.26)^{*}\end{array}$ & $\begin{array}{c}0.098 \\
(3.22)^{*}\end{array}$ \\
\hline Foreign Sales / Total Sales & $\begin{array}{c}0.370 \\
(4.12)^{*}\end{array}$ & $\begin{array}{l}0.039 \\
(0.53) \\
\end{array}$ & $\begin{array}{l}0.078 \\
(0.10) \\
\end{array}$ & $\begin{array}{c}0.293 \\
(3.29)^{*} \\
\end{array}$ & $\begin{array}{l}0.024 \\
(0.30) \\
\end{array}$ & $\begin{array}{l}0.042 \\
(0.49) \\
\end{array}$ & $\begin{array}{c}\text { Foreign Sales / Total } \\
\text { Sales }\end{array}$ & $\begin{array}{c}0.151 \\
(3.71)^{*}\end{array}$ & $\begin{array}{c}0.061 \\
(1.72)^{* *}\end{array}$ & $\begin{array}{l}0.050 \\
(1.41)\end{array}$ \\
\hline $\begin{array}{c}\text { (Foreign Sales / Total } \\
\text { Sales)*Flexible }\end{array}$ & $\begin{array}{c}0.295 \\
(2.82)^{*}\end{array}$ & $\begin{array}{c}0.205 \\
(2.39)^{*}\end{array}$ & $\begin{array}{c}0.256 \\
(2.58)^{*}\end{array}$ & $\begin{array}{c}0.369 \\
(3.55)^{*}\end{array}$ & $\begin{array}{c}0.303 \\
(3.30)^{*}\end{array}$ & $\begin{array}{c}0.309 \\
(2.88)^{*}\end{array}$ & $\begin{array}{c}\text { (Foreign Sales / Total } \\
\text { Sales)*Flexible }\end{array}$ & $\begin{array}{c}-0.066 \\
(-2.15)^{*}\end{array}$ & $\begin{array}{c}-0.106 \\
(-2.65)^{*}\end{array}$ & $\begin{array}{c}-0.097 \\
(-2.28)^{*}\end{array}$ \\
\hline $\begin{array}{c}\text { Foreign Operations } \\
\text { Dummy } \\
\end{array}$ & & $\begin{array}{c}0.074 \\
(3.14)^{*}\end{array}$ & $\begin{array}{c}0.070 \\
(1.88)^{* *}\end{array}$ & & $\begin{array}{c}0.052 \\
(2.10)^{*}\end{array}$ & $\begin{array}{c}0.112 \\
(2.74)^{*}\end{array}$ & $\begin{array}{c}\text { Foreign Operations } \\
\text { Dummy }\end{array}$ & & $\begin{array}{c}0.024 \\
(2.32)^{*} \\
\end{array}$ & $\begin{array}{c}0.025 \\
(2.44)^{*} \\
\end{array}$ \\
\hline $\begin{array}{c}\text { Foreign Assets / Total } \\
\text { Assets }\end{array}$ & & $\begin{array}{c}0.978 \\
(4.89)^{*}\end{array}$ & $\begin{array}{c}1.55 \\
(3.70)^{*}\end{array}$ & & $\begin{array}{c}0.724 \\
(3.27)^{*}\end{array}$ & $\begin{array}{c}1.49 \\
(3.32)^{*}\end{array}$ & $\begin{array}{c}\text { Foreign Assets / Total } \\
\text { Assets }\end{array}$ & & $\begin{array}{c}0.253 \\
(3.43)^{*}\end{array}$ & $\begin{array}{c}0.484 \\
(3.12)^{*}\end{array}$ \\
\hline Size & & $\begin{array}{c}0.126 \\
(19.29)^{*}\end{array}$ & $\begin{array}{c}0.125 \\
(12.29)^{*}\end{array}$ & & $\begin{array}{c}0.115 \\
(16.31)^{*}\end{array}$ & $\begin{array}{c}0.043 \\
(10.99)^{*}\end{array}$ & $\begin{array}{c}\text { Foreign Debt / Total } \\
\text { Debt }\end{array}$ & & $\begin{array}{c}0.144 \\
(4.76)^{*}\end{array}$ & $\begin{array}{c}0.128 \\
(4.19)^{*}\end{array}$ \\
\hline Ownership & & $\begin{array}{c}-0.088 \\
(-3.78)^{*}\end{array}$ & $\begin{array}{c}-0.181 \\
(-4.79)^{*}\end{array}$ & & $\begin{array}{c}-0.128 \\
(-3.57)^{*}\end{array}$ & $\begin{array}{c}-0.172 \\
(-4.29)^{*}\end{array}$ & Size & & $\begin{array}{c}0.021 \\
(7.52)^{*}\end{array}$ & $\begin{array}{c}0.022 \\
(7.53)^{*}\end{array}$ \\
\hline ADR & & $\begin{array}{c}0.155 \\
(6.54)^{*} \\
\end{array}$ & $\begin{array}{c}0.172 \\
(4.11)^{*}\end{array}$ & & $\begin{array}{c}0.087 \\
(3.47)^{*} \\
\end{array}$ & $\begin{array}{c}0.128 \\
(2.88)^{*} \\
\end{array}$ & Debt-to-Assets & & $\begin{array}{c}0.047 \\
(2.95)^{*}\end{array}$ & $\begin{array}{c}0.127 \\
(2.89)^{*}\end{array}$ \\
\hline Market-to-book & & $\begin{array}{l}-0.012 \\
(-0.38) \\
\end{array}$ & $\begin{array}{l}-0.016 \\
(-0.51) \\
\end{array}$ & & $\begin{array}{l}-0.049 \\
(-1.51) \\
\end{array}$ & $\begin{array}{l}-0.037 \\
(-0.99) \\
\end{array}$ & Tax & & $\begin{array}{c}0.012 \\
(1.85)^{* *}\end{array}$ & $\begin{array}{l}-0.249 \\
(-0.47) \\
\end{array}$ \\
\hline Gross Margin & & $\begin{array}{l}0.020 \\
(1.51)\end{array}$ & $\begin{array}{l}0.014 \\
(1.14) \\
\end{array}$ & & $\begin{array}{l}0.086 \\
(0.97) \\
\end{array}$ & $\begin{array}{l}0.085 \\
(0.84) \\
\end{array}$ & Market-to-book & & $\begin{array}{c}0.028 \\
(2.64)^{*} \\
\end{array}$ & $\begin{array}{c}0.025 \\
(2.35)^{*}\end{array}$ \\
\hline Current Ratio & & $\begin{array}{c}-0.039 \\
(-4.34)^{*} \\
\end{array}$ & $\begin{array}{c}-0.049 \\
(-3.51)^{*}\end{array}$ & & $\begin{array}{c}-0.047 \\
(-4.80)^{*} \\
\end{array}$ & $\begin{array}{c}-0.060 \\
(-3.91)^{*}\end{array}$ & Current Ratio & & $\begin{array}{l}-0.030 \\
(-0.01) \\
\end{array}$ & $\begin{array}{l}-0.037 \\
(-0.74) \\
\end{array}$ \\
\hline Cross variables & No & No & Yes & No & No & Yes & Cross variables & No & No & Yes \\
\hline Sectoral Dummies & Yes & Yes & Yes & Yes & Yes & Yes & Sectoral Dummies & Yes & Yes & Yes \\
\hline Time Dummies & Yes & Yes & Yes & Yes & Yes & Yes & Time Dummies & Yes & Yes & Yes \\
\hline $\mathbf{N}$ & 1980 & 1980 & 1980 & 1980 & 1980 & 1980 & $\mathbf{N}$ & 1980 & 1980 & 1980 \\
\hline Pseudo-R2 & 0.099 & 0.358 & 0.380 & 0.145 & 0.309 & 0.359 & Pseudo-R2 & 0.448 & 0.857 & 0.905 \\
\hline
\end{tabular}


Table 6 - The determinants of corporate financial policies

Table 6 shows the results of the estimation of (1) without the interaction variable by dividing the sample in two time-periods through a pooled OLS estimation. Fixed represents the estimation of (1) under the fixed exchange rate regime from 1996 to 1998. Flexible represents the estimation using data from 2000 to 2006. Controls, sectoral and time dummies are added to the estimation. * stands for $5 \%$ level of significance.

\begin{tabular}{|c|cc|cc|cc||}
\hline \hline & \multicolumn{2}{|c|}{ Foreign Debt / Total Debt } & \multicolumn{2}{c|}{$\begin{array}{c}\text { Net) Foreign Debt / } \\
\text { Total Debt }\end{array}$} & \multicolumn{2}{c|}{ Derivatives / Total Assets } \\
\hline \hline Variable & \multicolumn{2}{|c|}{ Fixed } & Flexible & Fixed & Flexible & \multicolumn{2}{c|}{ Fixed } & Flexible \\
\hline \hline \multirow{2}{*}{ Foreign Sales / Total Sales } & -0.022 & 0.274 & -0.029 & 0.309 & 0.011 & -0.020 \\
& $(-0.30)$ & $(5.20)^{*}$ & $(-0.39)$ & $(5.41)^{*}$ & $(0.12)$ & $(-2.08)^{*}$ \\
\hline Controls & Yes & Yes & Yes & Yes & Yes & Yes \\
Sectoral Dummies & Yes & Yes & Yes & Yes & Yes & Yes \\
Time Dummies & Yes & Yes & Yes & Yes & Yes & Yes \\
\hline \hline N & 540 & 1260 & 540 & 1260 & 540 & 1260 \\
R2 & 0.313 & 0.456 & 0.277 & 0.318 & 0.328 & 0.340 \\
\hline
\end{tabular}

Table 7 - The determinants of corporate financial policies - Quantile estimation

Table 7 shows the estimation of (1) using a conditional quantile estimator. Results are shows for 10 to 90 quantile. All estimations include control variables, sectoral and time dummies. * stands for $5 \%$ level of significance.

\begin{tabular}{|c|c|c|c|c|c|c|c|c|}
\hline \multicolumn{9}{|c|}{ Foreign Debt / Total Debt } \\
\hline Variable & Q20 & Q30 & Q40 & Q50 & Q60 & Q70 & Q80 & Q90 \\
\hline Flexible & $\begin{array}{c}-0.12 \\
(-4.28)^{*}\end{array}$ & $\begin{array}{c}-0.17 \\
(-5.16)^{*}\end{array}$ & $\begin{array}{c}-0.19 \\
(-4.10)^{*}\end{array}$ & $\begin{array}{c}-0.24 \\
(-6.47)^{*}\end{array}$ & $\begin{array}{c}-0.25 \\
(-4.93)^{*}\end{array}$ & $\begin{array}{c}-0.32 \\
(-6.64)^{*}\end{array}$ & $\begin{array}{c}-0.36 \\
(-6.20)^{*}\end{array}$ & $\begin{array}{c}-0.23 \\
(-3.90)^{*}\end{array}$ \\
\hline Foreign Sales / Total Sales & $\begin{array}{c}0.06 \\
(0.09)\end{array}$ & $\begin{array}{c}0.17 \\
(2.16)^{*}\end{array}$ & $\begin{array}{c}0.13 \\
(1.42)\end{array}$ & $\begin{array}{c}0.064 \\
(0.81)\end{array}$ & $\begin{array}{l}0.062 \\
(0.85)\end{array}$ & $\begin{array}{l}0.064 \\
(0.81)\end{array}$ & $\begin{array}{l}-0.038 \\
(-0.46)\end{array}$ & $\begin{array}{c}-0.13 \\
(-2.02)^{*}\end{array}$ \\
\hline $\begin{array}{c}\text { (Foreign Sales / Total Sales) } \\
{ }^{*} \text { Flexible }\end{array}$ & $\begin{array}{c}0.11 \\
(1.21) \\
\end{array}$ & $\begin{array}{l}0.011 \\
(0.12)\end{array}$ & $\begin{array}{c}0.02 \\
(0.14) \\
\end{array}$ & $\begin{array}{l}0.039 \\
(0.42) \\
\end{array}$ & $\begin{array}{l}0.058 \\
(0.61) \\
\end{array}$ & $\begin{array}{l}0.039 \\
(0.42) \\
\end{array}$ & $\begin{array}{c}0.252 \\
(2.53)^{*}\end{array}$ & $\begin{array}{c}0.260 \\
(4.08)^{*}\end{array}$ \\
\hline Controls & Yes & Yes & Yes & Yes & Yes & Yes & Yes & Yes \\
\hline Sectoral Dummies & Yes & Yes & Yes & Yes & Yes & Yes & Yes & Yes \\
\hline Time Dummies & Yes & Yes & Yes & Yes & Yes & Yes & Yes & Yes \\
\hline $\mathbf{N}$ & 1980 & 1980 & 1980 & 1980 & 1980 & 1980 & 1980 & 1980 \\
\hline Pseudo-R2 & 0.225 & 0.287 & 0.302 & 0.297 & 0.271 & 0.228 & 0.173 & 0.102 \\
\hline \multicolumn{9}{|c|}{ (Net) Foreign Debt / Total Debt } \\
\hline Variable & Q20 & Q30 & Q40 & Q50 & Q60 & Q70 & Q80 & Q90 \\
\hline Flexible & $\begin{array}{l}-0.032 \\
(-1.42)\end{array}$ & $\begin{array}{l}-0.053 \\
(-1.43)\end{array}$ & $\begin{array}{l}-0.065 \\
(-1.38)\end{array}$ & $\begin{array}{l}-0.078 \\
(-1.28)\end{array}$ & $\begin{array}{c}-0.078 \\
(-1.94)^{* *}\end{array}$ & $\begin{array}{l}-0.072 \\
(-1.42)\end{array}$ & $\begin{array}{c}-0.105 \\
(-2.07)^{*}\end{array}$ & $\begin{array}{l}-0.102 \\
(-2.18)^{*}\end{array}$ \\
\hline Foreign Sales / Total Sales & $\begin{array}{l}0.035 \\
(0.44)\end{array}$ & $\begin{array}{l}0.106 \\
(1.12)\end{array}$ & $\begin{array}{l}0.125 \\
(1.29)\end{array}$ & $\begin{array}{l}0.076 \\
(0.75)\end{array}$ & $\begin{array}{l}0.108 \\
(1.18)\end{array}$ & $\begin{array}{l}0.046 \\
(0.41)\end{array}$ & $\begin{array}{l}-0.063 \\
(-0.61)\end{array}$ & $\begin{array}{l}-0.149 \\
(-1.38)\end{array}$ \\
\hline (Foreign Sales / Total Sales) & 0.098 & 0.108 & 0.051 & 0.135 & 0.146 & 0.168 & 0.263 & 0.372 \\
\hline *Flexible & $(0.97)$ & $(1.15)$ & $(0.48)$ & $(1.62)$ & $(1.29)$ & $(1.71)^{* *}$ & $(2.34)^{*}$ & $(3.22)^{*}$ \\
\hline Controls & Yes & Yes & Yes & Yes & Yes & Yes & Yes & Yes \\
\hline Sectoral Dummies & Yes & Yes & Yes & Yes & Yes & Yes & Yes & Yes \\
\hline Time Dummies & Yes & Yes & Yes & Yes & Yes & Yes & Yes & Yes \\
\hline $\mathbf{N}$ & 1980 & 1980 & 1980 & 1980 & 1980 & 1980 & 1980 & 1980 \\
\hline Pseudo-R2 & 0.102 & 0.183 & 0.228 & 0.238 & 0.235 & 0.210 & 0.175 & 0.117 \\
\hline
\end{tabular}


Figure 1 - The distribution of companies' foreign currency denominated debt

Figure 1 shows the results of the semi-parametric procedure proposed by DiNardo, Lemieux and Fortin (1996) for the unconditional distribution of companies' foreign currency debt. The First graph (left) shows the distribution of the ratio of foreign debt to total debt. The second graph (right) shows the distribution of the ratio of (net) foreign debt to total debt. Pegged represents the actual distribution under the fixed exchange rate regime. Floating represents the counter-factual distribution under a floating exchange rate regime.
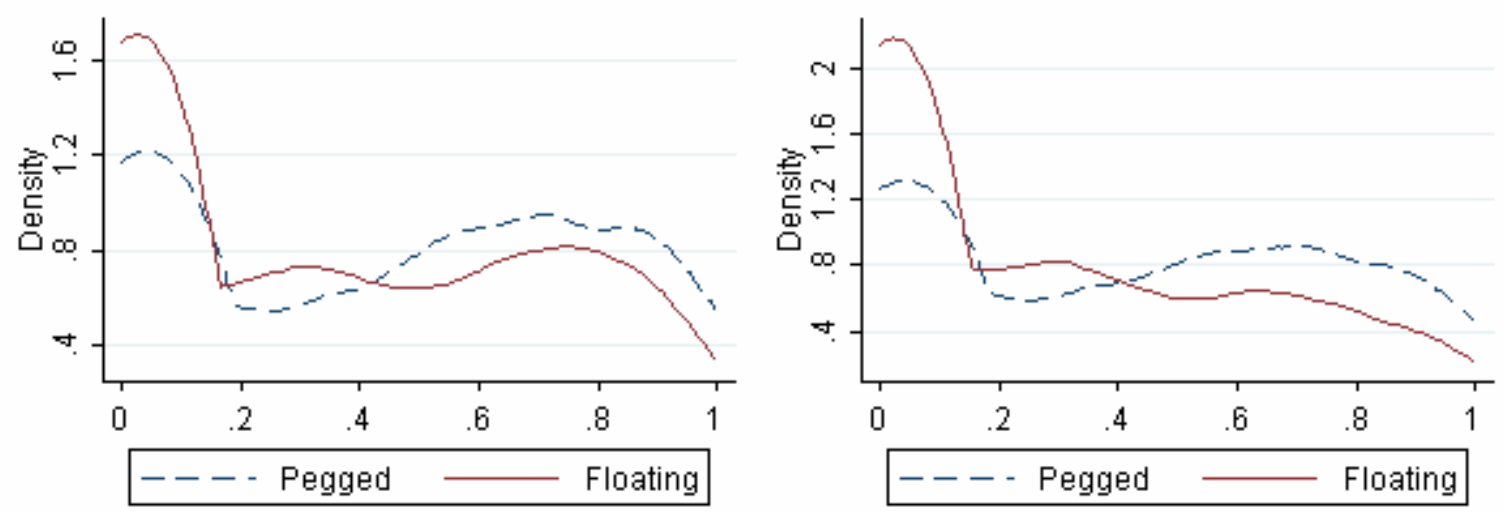